\title{
Çağrışım Belleği Üzerine Bir Gözden Geçirme
}

\author{
Hatice Dedetaş ${ }^{1}$ \\ Orta Doğu Teknik Üniversitesi
}

Aslı Kılıç 2

Orta Doğu Teknik Üniversitesi

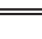

Özet

Olaysal bellek, insanların yaşadıkları olayların içeriğini zamana ve mekâna bağlı olarak bilinçli bir şekilde hatırlayabilme yetisi olarak tanımlanmıştır. Olaysal bellekte depolanan bilgiler, yaşanan olayların arasında oluşan çağrışımları da barındırmaktadır. Belleğe kodlanan çağrışımlar, laboratuvar ortamında çeşitli bellek görevleri aracılığ ile çalışılmaktadır. Bu gözden geçirmenin amacı alanyazında detaylıca çalışılmış olan çağrışım belleği görevlerinin yalnızca olayların içeriklerinin (maddelerin) kodlanmasının yeterli olduğu görevlerden (ör. tanıma belleği, serbest hatırlama) nasıl farklılaştığını değerlendirmektir. Bu doğrultuda, çağrışım belleği görevlerinde çağrışım bilgisinin nasıl kodlandığı, daha sonra kodlanan çağrışımların nasıl geri çağrıldı̆̆ ve maddeler arasındaki çağrışımın simetrik olup olmadığı üzerine temellendirilmiş hipotezler değerlendirilmiştir.
\end{abstract}

Anahtar kelimeler: Çağrışım belleği, çağrışımlar, bağımsız çağrışım, simetrik çağrışım, olaysal bellek

\begin{abstract}
Episodic memory is defined as the ability of consciously remembering the temporal and spatial content of events. In addition to the content information, episodic memory also stores the associations among events. In the literature, associative memory is investigated in detail through a variety of memory tasks in laboratory settings. The purpose of this review is to evaluate memory tasks that allow measuring how associations among items are formed differently when compared to memory tasks that do not require explicit association formation (e.g., item recognition, free recall). To this end, how associative information is encoded in associative memory tasks, how the associations are recalled and the hypotheses about whether associations are symmetric or not are evaluated in the current review.
\end{abstract}

Keywords: Association memory, associations, independent association, symmetric association, episodic memory

Yazışma Adresi: 'Arş. Gör. Hatice Dedetaş, Orta Doğu Teknik Üniversitesi, Fen Edebiyat Fakültesi, Psikoloji Bölümü, Ankara, hdedetas@metu. edu.tr, ORC-ID: 0000-0003-4078-448X

${ }^{2}$ Doç. Dr., Orta Doğu Teknik Üniversitesi, Fen Edebiyat Fakültesi, Psikoloji Bölümü, Ankara, askilic@metu.edu.tr, ORC-ID: 0000-00026052-9796

Gönderim Tarihi: 23.05 .2019

Kabul Tarihi: 01.10.2020 


\section{Çağrıșım Belleği}

Olaysal bellek (episodic memory), insanların kişisel geçmişlerinde yaşadıkları olayları bilinçli olarak ve genellikle içerik, zaman ve mekân özelliklerini de barındırarak hatırlamasıdır (Tulving, 1972, 1985, 2002). Tulving (1985, 2002), insanların geçmişte yaşadıkları anılarını hatırlayabilme kabiliyetlerini "zihinsel zaman yolculuğu" olarak tanımlamıştır. Olaysal bellek, benlik algısını ve olayın geçmişte yaşanmış olduğu farkındal1ğını gerektiren kişisel bir deneyimdir (Tulving, 2002). Hayatımızın neredeyse her anında olaysal bellek hatırlamaları yapmamız nedeniyle olaysal bellek günlük yaşantımızda çok önemli bir yer teşkil eder.

Olaysal bellek araştırmaları literatürde genellikle çeşitli uyaranlar (ör. resim, ses, kelimer) aracılığıyla yapılır (Tulving, 1992). Günlük hayatla örnekleyecek olursak, "dün sabah kahvaltıda ne yediniz" sorusuna vereceğiniz her cevap bir maddedir. Bu referans noktası ile düşünecek olursak, standart bir bellek deneyinde katılımcılardan kelime listelerini çalışmaları istenir ve çeldirici bir görevin ardından listeden neleri hatırladıkları farklı yöntemler ile test edilir. Katılımcıların çalıştıkları kelimeleri akıllarına geldiği sıra ile rapor etmesine serbest hatırlama görevi denir (Tulving, 1992). Katılımcılara çalıştıkları kelimeleri yeni kelimeler eşliğinde sunup, çalıştıkları kelimeleri yeni kelimelerden ayırt etmesine ise tanıma görevi denir. Madde bilgilerinin hatırlanması ya da tanınması önemli olduğu gibi maddelerin hangi liste konumunda çalışılmasının bir avantaj sağladığı veya kelimelerin ne gibi özelliklerinin hatırlanabilme oranını artırdığı gibi soruların cevabı da olaysal belleğin çalışma mekanizması hakkında bilgi verir.

Olaysal belleği etkileyen bir diğer faktör de çalış1lan maddelerin içerikleri arasındaki ilişkidir (Underwood, 1969). Örneğin, hatırlanan bir olay başka bir olay1 çağrıştırabilir ve böylece diğer olayın hatırlanması da daha kolay olur. Bu nedenle, olaylar arasında oluşan çağrışımlar olaysal belleği açıklamaya çalışan mekanizmaları anlamada önemli bir yere sahiptir. Örneğin, iki olay arasında oluşan ilişkinin olayların zamansal olarak birbirlerine yakınlıklarından mı (Kahana, 2002), bu iki olayın birleşerek yeni bir temsiliyet oluşturduklarından mı (Madan, Glaholth, ve Caplan, 2010) ya da iki olayın birbirlerine bağlanması sonucunda mı (Hockley ve Cristi, 1996) oluştuğu net değildir. Kısaca, çağrışımlar olaysal belleğin işleyişi hakkında kapsamlı veri sunduğu için çağrışım belleğinin altında yatan mekanizmaları anlamak olaysal bellekteki kuramsal yaklaşımlar için önemlidir.

Çağrışım belleği alanyazınında kelimeler veya görseller gibi uyarıcılar arasındaki ilişkinin nasıl kurulduğu ve sonrasında bir uyarıcının ipucu olarak kullanılması ile diğerinin nasıl hatırlandı̆̆ çalışılır. Bir sonraki bölümde çağrışım belleği alanyazınında kullanılan görevler özetlenecektir. Sonrasında, madde bilgisi ile çağrışım bilgisinin hangi konularda ne şekilde farklılık gösterdiği, madde bilgisinden farklı olan çağrışım bilgisinin ne şekilde kodlandığ1 ve çağrışımın simetrik olup olmadı ̆̆ üzerine oluşturulmuş iki önemli hipotez açıklanacaktır. Daha sonra da alanyazınında sunulan bulgular bu çerçevede tartışılacaktır.

\section{Çağrıșım Belleği Görevleri}

Olaysal bellekte çağrışım bilgisini ölçmek için iki temel görev kullanılır: ipuçlu hatırlama (cued recall) ve çağrışımsal tanıma (associative recognition, Kahana, 2012). İpuçlu hatırlama, çalışma-test yöntemi ve tahmin (anticipation) yöntemi olarak ikiye ayrılır. Çalıșma-test yönteminde katılımcılara öncelikle kelime çiftleri sıra ile gösterilir $\left(X_{1}-Y_{1}, X_{2}-Y_{2}, X_{3}-Y_{3}, \ldots X_{n}-Y_{n}\right)$ ve sonra test sırasında kelimelerden biri ipucu olarak sunulup çiftinin ne olduğu sorulur $\left(\mathrm{X}_{1}-\right.$ ?, ? $-\mathrm{Y}_{2}, \mathrm{X}_{3}-?, \ldots \mathrm{Y}_{\mathrm{n}}-$ ?, Ensor, Guitard, Bireta, Hockley, ve Surprenant, 2019; Wilson, Kellen ve Criss, 2019). X'lerin ipucu olarak verilip Y'lerin sorulması ileriye doğru hatırlama (forward recall), Y'lerin ipucu olarak verilip X'lerin sorulması ise geriye doğru hatırlama (backward recall) olarak adlandırılmıştır. Tahmin yönteminde ise katılımcılara X kelimesi gösterilir ve $\mathrm{Y}$ kelimesini tahmin etmeleri için süre verilir. $\mathrm{Y}$ kelimesini tahmin edemediklerinde Y kelimesi gösterilir ve liste katılımcilar Y kelimelerini belirli oranda doğru bilinceye kadar bu şekilde sunulmaya devam eder (Dennis, ve Kruschke, 1998). Yani tahmin yönteminde çalışma ve test iç içe yer almaktadır (Kahana, 2012).

Yukarıda bahsedildiği gibi, çağrışımsal hatırlamayı çalışmanın bir diğer yöntemi de çağrışımsal tanımadır. İpuçlu hatırlamada olduğu gibi kelime çiftleri sıra ile gösterilir $\left(X_{1}-Y_{1}, X_{2}-Y_{2}, X_{3}-Y_{3}, \ldots X_{n}-Y_{n}\right)$. Bu yöntem, ipuçlu hatırlama yönteminden test kısmında ayrılır. Şöyle ki, katılımcılara $X_{1}-Y_{1}$ ve $X_{2}-Y_{3}$ şeklinde çiftler gösterilerek, bu kelime çiftlerini çalışma sırasında birlikte görüp görmedikleri sorulur. Test k1smında gösterilen kelime çiftleri çalışma kısmında gösterilen kelimelerden oluşur. Bazı çiftler çalışma kısmında olduğu şekilde verilirken ( $X_{1}-Y_{1}$, bozulmamış, intact), bazı çiftler çalışma kısmında farklı çiftlerden alınan kelimelerin bir araya getirilmesi ile oluşturulur $\left(\mathrm{X}_{2}-\mathrm{Y}_{4}\right.$, yeniden düzenlenmiş, rearranged). Katılımcılardan beklenen ise çalışma kısmında gösterilen çiftleri tanımalarıdır. Test kısmında sunulan çiftlerin hepsi çalışma kısmındaki kelimelerden oluştuğu için bu test türü katılımcıların gördükleri kelimeleri çalışma kısmında çift olarak görüp görmediklerine karar vermelerini, yani kelimeler arasında kurdukları ilișkiyi hatırlamalarını gerektirmektedir. Madde tanıma ve çağrışımsal tanıma bellek performansları arasındaki 
farkın, çağrışımların bellek performansı üzerine olan etkisini göstermekte olduğu düşünülmektedir ve bu doğrultuda çalışmalar yapılmıştır (örn., Cox ve Criss, 2017; Gronlund ve Ratcliff, 1989; Jackson ve Greene, 2017; Hockley, 1992; Hockley ve Cristi, 1996; Nobel ve Shiffrin, 2001; Osth ve Fox, 2019).

Yukarıda bahsedilen görevlerde çalışma kısımları birbiri ile benzerlik göstermektedir ancak çalışmanın amacına bağlı olarak, test tipinden bağımsız olacak şekilde çalışma kısımları da değişimlenebilir. Örneğin, Criss, Aue ve Smith (2011) deneylerinin çalışma kısmında katılımcılardan gösterilen her kelime çiftinden cümle kurmalarını istemişlerdir. Böylece iki kelime arasındaki ilişkinin oluşturulmasını cümle kurma yöntemi ile sağlamışlardır. Başka bir örnek olarak da katılımcılardan çiftte bulunan kelimelerin ne kadar ilișkili olduklarını bir skala üzerinde değerlendirmeleri istenir (Popov, Zhang, Koch, Calloway, ve Coutanche, 2019). Bazı deneylerde ise katılımcılardan sadece iki kelimeyi birlikte öğrenmeleri veya birlikte hayal etmeleri istenebilir (McGee, 1980).

Çiftler ile oluşturulan kodlama yöntemlerine ek olarak, Kahana (2002) üçlü yoklayıcı hatırlama (probed recall) görevi aracılığı ile çağrışımların belirli bir yön ile mi yoksa bütün olarak mı kurulduğunu açıklamayı amaçlayan simetrik ve bağımsız çağrışım hipotezlerini test etmiștir. Bu görevde, çalıșma aşamasında üç kelime birlikte gösterilmiş (A-B-C) ve test aşamasında altı farklı şekilde katılımcılara sunulmuştur: iki maddeli ipuçları (AB?) ve (?BC) ve tek maddeli ipuçları (A?_, ?B_,_B?, ve _?C). Yine bu iki hipotezin sınanması için yapılan bir başka çalışmada, üçlüler çağrıșımsal tanıma testiyle de kullanılmıştır (Yang, Zhu, Mecklinger, Fang, ve Li, 2013). Bu testte A-B-C, X-Y-Z olarak birlikte gösterilen üçlüler test aşamasında kelimelerin yerleri değiştirilerek (rearranged) veya değiştirilmeyerek (intact) bu üçlüyü bu sıra ile gösterilip gösterilmediklerine karar vermeleri istenmiştir. Yukarıda bahsi geçen hipotezler daha detaylı bir şekilde makalenin sonraki bölümlerinde tartışılacaktır.

Yoklayıcı hatırlama görevinin kullanıldığı bir başka çalışmada, Kilic, Criss ve Howard (2013) kelimeler arasındaki ilişkinin, kelimeler çift olarak sunulmadan bile zamansal olarak da kurulabildiğini göstermiştir. Çalışmada katılımcılara aritmetik görev ile ayrılan 6 blok kelime listeleri sunulmuştur ve çalışma safhasının bitiminde çalışılan her listeden seçkisiz olarak kelimeler gösterilmiştir. Katılımcılardan sunulan kelimenin bulunduğu listede yer alan başka bir kelime hatırlamaları istenmiştir. Deneyden elde edilen sonuçlar, katılımcıların yoklayıcı olarak sunulan kelimenin bulunduğu listeye geri dönebildiğini ve o listeden yoklayıcı kelimeye zamansal olarak yakın olan, yani çalışma aşamasında yoklayıcı kelimenin sunulduğu liste konumuna yakın başka bir kelimeyi geri çağırabildiklerini göstermiştir. Bu da katılımcılardan kelimeler arası bir ilişki kurulması açık olarak istenmediğinde bile liste boyunca çalışılan kelimelerin zamansal olarak da birbirlerini çağrıştırabileceğine işaret etmektedir.

Diğer taraftan, zamansal olarak kurulan çağrışımların kelime çiftleri test edildiğinde etkili olmayabileceği de tartışılmıştır (Hintzman, 2016). Katılımcılara seçkisiz olarak oluşturulan kelime çiftlerinin sunulduğu ve daha sonra bu kelimelerin ipuçlu hatırlama görevi ile test edildiği bir çalışmada, katılımcılar kelimenin çifti yerine listeden yanlış bir kelime çağırdığında, bu yanlış kelime çalışma aşamasında hedef kelime çiftinin sunum konumuna yakın konumda sunulan başka bir kelime çiftinden üretilmiştir (Davis, Geller, Rizzuto ve Kahana, 2008). Örneğin, $X_{1}-Y_{1}, X_{2}-Y_{2}, X_{3}-Y_{3}, X_{4}-Y_{4} X_{5}-Y_{5}$ kelime çiftleri çalışıldıktan sonraki test aşamasında $X_{4}$ kelimesi ipucu olarak verildiğinde ve $\mathrm{Y}_{4}$ hedefi hatırlanmadığında, katılımcıların yanlışlıkla Y3 veya Y5 kelimesini çağırma olasılığının Y1 kelimesini çağırma olasılığından daha yüksek olduğu görülmüştür. Bu da kelime çiftleri arasında zamansal olarak yakın olmalarından kaynaklanan bir çağrıșım olması ile açıklanmıştır. Ancak, Hintzman (2016) bu bulguların altında Kahana ve ekibinin önerdiği gibi zamana bağlı olarak kurulan çağrışımları temel alan bir mekanizma olmadığı, onun yerine katılimcıların deney sırasından onlardan ne bekleneceğini öngörüp, beklentileri karşılayacak şekilde kelimeleri kodladıklarını belirtmiştir. Daha sonra bu hipotezi çağrışımsal tanıma görevi ile test eden Osth ve Fox (2019), birbirinden uzak konumlarda çalışılan kelime çiftlerinin yeniden düzenlendiği koşullar $\left(\mathrm{X}_{1}-\mathrm{Y}_{5}\right)$ ile birbirlerine yakın konumlarda çalışılan çiftlerin $\left(\mathrm{X}_{3}-\mathrm{Y}_{4}\right)$ yanlışlıkla birlikte çalışılmış olarak kabul edilmesinde bir fark olmadığını göstermiştir. Bu da çiftler arasındaki ilişkinin zamansal yakınlığa bağlı olarak kodlandığı savını zayıflatmaktadır. Kısaca, çokça araştırılmış olan çağrışımsal bellek görevleri farklı biçimlerde analiz edildiğinde farklı kuramları destekleyebilmektedir.

$\mathrm{Bu}$ bölümde listelenen bellek görevlerinin uygulanması sonucunda elde edilen bulguların madde ve çağrışım bilgilerini ne ölçüde farklılaştığı veya ne ölçüde birbirlerine bağlı olduğu bir sonraki bölümde kapsamlı olarak irdelenecektir.

\section{Madde Bilgisi ile Çağrışım Bilgisinin Farkları}

Madde bilgisi bir uyarıcının varlığını ve içerik bilgisini temsil ederken çağrışım bilgisi maddeler/olaylar arasındaki ilişkiyi temsil eder (Humphreys, 1976, 1978; Murdock, 1997). Örneğin, çağrışım bilgisi iki kelimenin çift olarak birlikte çalışıldığının ve aralarında oluşan bağlantının bilgisidir. Madde ve çağrışım bilgisi arasındaki bu fark uzun süredir ipuçlu hatırlama yerine çağrışımsal tanıma testinin madde tanıma testi (item re- 
cognition) ile kıyaslanması aracılığıyla araştırılmaktadır. Bunun sebebi de, ipuçlu hatırlama görevlerinde madde ve çağrışım bilgilerinin birbirinden bağımsız olarak ölçülememesidir. (Ceraso ve Henderso, 1965). Buna alternatif olarak, çağrışımsal tanıma testinin daha sade bir araç olduğu ve madde ile çağrışım bilgilerini kıyaslamak için daha güvenilir bir metot olduğu düşünülmektedir (Hockley, 1992).

Gronlund ve Ratcliff (1989) madde ve çağrışım bilgisine erişim sürelerinin farklı olduğunu göstermiştir. Gronlund ve Ratcliff deneylerinin çalışma kısmında hem kelime çiftleri hem de bireysel kelimeler sunmuştur. Akabinde, test kısmında tanıma ve çağrışımsal tanıma testlerini sinırlı sürede cevap verme (response deadline procedure) yöntemini kullanarak uygulamıştır. Bu yöntemde katılımcılar kendi istedikleri zaman cevap vermek yerine test öğesini gördükten sonra onlara sunulan bir işareti takiben cevap verirler. $\mathrm{Bu}$ işaretler seçkisiz olarak değişimlenen $60 \mathrm{~ms}$ ile $3 \mathrm{~s}$ aralığındaki 7 zaman koşullarında sunulur. Böylece bilginin ne aşamada doğru cevap verilebilecek kadar biriktiği, bilginin birikme hızı ve erişilebilecek toplam bilginin ne düzeyde olduğu anlaşılabilir. Örneğin, cevap vermek için 500 ms beklendiğinde doğru yanıt verme oranı 200ms beklendiğinde doğru yanıt verme oranından çok daha fazladır. Böylece, bilginin zamana bağlı hangi hızda biriktiği ölçülebilmiş olacaktır. Diğer taraftan, doğru yanıt oranı $1.5 \mathrm{~s}$ ile $3 \mathrm{~s}$ arasında büyük bir değişiklik göstermemektedir. $\mathrm{Bu}$ da, elde edilebilecek toplam bilgiye 1.5 saniyede erişildiğini ve katılımcıya daha fazla zaman verilse bile tanıma performansının artmayacağını gösterir. Gronlund ve Ratcliff (1989) de bu araştırmalarında madde ve çağrışım bilgilerinin birbirinden farklı sürelerde biriktiğini, çağrışımsal tanıma testine doğru cevap verme süresinin madde tanıma testine doğru cevap verme süresinden daha uzun olduğunu göstermişlerdir.

Madde ve çağrışım bilgilerine erişim sürelerinin farklı olduğu daha güncel bir çalışma ile de ortaya konmuştur. Mohanty ve Naveh-Benjamin (2018) yaptıkları çalışmada katılımcılara kelime ve resimlerden oluşan çiftler göstermişlerdir ve katılımcıları sınırlı sürede cevap verme yöntemi ile test etmişlerdir. Test sırasında yeni resim, yeni resim-kelime çiftleri, çalışılmış resimler ve resim-kelime çiftleri gösterilmiş, katılımcılardan gösterilen resmi veya çifti çalışma kısmında görüp görmediği sorulmuştur. Böylece madde ve çağrışım bellek performansları test edilmiştir. Araştırma sonuçlarında bellek tipi ve süre kısıtlaması etkileşimi bulunmuştur. Öyle ki, tek başına gösterilen resimlerde kısa süre ve uzun sürede verilen doğru cevap oranı arasındaki fark çiftlere verilen cevaplara kıyasla daha azdır. Bir başka deyişle, süre k1sıtlaması madde bilgilerine erişimi çok fazla etkilemezken, çağrışım bilgilerine erişimi zayıflatmaktadır.
Ayrıca, Gronlund ve Ratcliff (1989) deneylerinin çalışma aşamasında A-B kelime çiftlerinin yanında bir de bireysel kelimeler (C) sunmuşlardır. Daha sonra, test aşamasında da A-B (bozulmamış), A-B' (yeniden düzenlenmiş), X-Y (yeni) çiftlerin ve C (çalışılan) kelimelerin ne hızda ve ne doğrulukta tanındığını incelemişlerdir. Elde edilen sonuçlara göre A-B çiftlerinin X-Y çiftlerinden ayrışabilirliği A veya $C$ kelimelerinin yeni bir $X$ kelimesinden ayrışabilirliğinden daha fazladır. $\mathrm{Bu}$ da, A-B kelimelerinin oluşturduğu çağrışımların tek başına $\mathrm{A}$ kelimesinin tanınmasına kıyasla daha avantajlı olduğunu göstermiştir. Kısaca, doğru kodlanan çağrışım bilgisini bellekten geri çağırmak, madde bilgisini geri çağırmaktan daha avantajlıdır. Buna ek olarak, A-B' (yeniden düzenlenmiş) kelime çiftlerine verilen yanlış "evet" yanıt oranı X-Y kelime çiftlerine verilen yanlıș "evet" oranı ile kıyaslandığında, A-B' kelime çiftlerine verilen yanıtların bilgi işleme süresinin başlarında (ör. $200 \mathrm{~ms}$ ) arttığını ancak çağrışımsal bilgiye ulaşıldıktan sonra (ör. 600 $\mathrm{ms}$ ) yanlış yanıt oranının azaldığını göstermişlerdir. $\mathrm{Bu}$ bulgular, çağrışımsal bilgilere erișimin madde bilgilerine erișimden daha yavaş olduğu görüşünü desteklemektedir. Bu da, temel olarak çağrışımsal bilginin belleğe kodlanırken birleşik yeni bir öğe olarak kodlanabileceğini ve daha sonra bu yeni çağrışımsal bilgiyi geri çağırmak için de tanımaya ek olarak hatırlama süreçlerinin de devreye girebileceğini göstermektedir.

Madde ve çağrışım bilgilerinin farklı bir süreçle kodlandığını ve unutulduğunu öne süren başka çalışmalar da bulunmaktadır (Hockley, 1991, 1992; McGee, 1980). McGee (1980) katılimcilara bireysel kelimeler ve kelime çiftleri sunduğu deneylerde katılımcılardan kelimeleri akıllarında canlandırarak öğrenmeye çalışmalarını istemişlerdir. Deneyin bir koşulunda kelimeleri ayrı ayrı, diğer koşulunda ise çift olarak akılda canlandırmalarını istemişlerdir. Deneyin sonuçlarına göre madde tanıma testi ile teker teker sorulan kelimeler çalışma kısmında ayrı ayrı hayal edilerek kodlandığında daha iyi hatırlanırken, çağrışımsal tanıma testi ile çift olarak sorulan kelimeler çalışma kısmında birlikte hayal edildiklerinde daha iyi hatırlanmışlardır. Bu da göstermektedir ki bireysel kelimeler ile kelime çiftlerinin kodlanmaları birbirinden farklı süreçler içermektedir.

Hockley'nin (1991, 1992) elde ettiği bulgulara göre, madde bilgisi çağrışım bilgisine oranla çürümeye ve unutulmaya daha yatkındır. Örneğin, Hockley (1991) katılımcılara kelime çiftlerini gösterdikten sonra kat1lımcıları bireysel kelimeleri, bireysel yeni kelimelerden (madde tanıma testi) ve kelime çiftlerini, yeniden düzenlenmiş kelime çiftlerinden (çağrışımsal tanıma testi) ayırma kabiliyetlerine göre test etmiştir. Bireysel kelimelerin ve kelime çiftlerinin aynı tip kaynaktan (yani A-B kelime çiftlerinden) gelmesi bu çalışmanın avanta- 
j1 olarak görülmektedir (Hockley, 1992). Bu çalışmanın sonuçlarına göre madde bilgisi gecikmeli testte azaldığ 1 halde çağrışım bilgisi bu gecikmeden etkilenmemiştir. Yani madde tanıma testindeki performans zamanla düşerken çağrışımsal tanıma performansında zamana bağlı bir düşüş istatistiksel olarak ortaya çıkmamıştır. Bu da madde ve çağrışım belleklerinde unutma sürelerinin birbirinden farklı olduğu görüşünü desteklemektedir.

Bunların dışında, kelimelerin kullanım sıklığı özelliklerinin madde tanıma ve çağrışımsal tanıma testlerini farklı etkilediğini bulunmuştur (Clark, 1992; Clark ve Burchett, 1994; Clark ve Shiffrin, 1992; Hockley, 1994). Örneğin, Clark ve Burchett (1994) araştırmalarında katılımcılara sadece yüksek sıklıkta kelimelerden oluşan çiftleri ve sadece düşük sıklıkta kelimelerden oluşan çiftleri aynı listede veya farklı listelerde sunmuşlardır. Daha sonra madde tanıma, çağrışımsal tanıma ve ipuçlu hatırlama görevleri ile test edilmişlerdir. İpuçlu hatırlama ve çağrışımsal tanıma testlerinde yüksek sıklıktaki kelimeler performansı artırırken, madde tanıma testinde düşük sıklıktaki kelimeler performansı artırmıșlardir (Clark ve Burchett, 1994). Ayrica, Aue, Fontaine ve Criss'in (2018) de yaptıkları çalışmada düşük sıklıktaki kelimelerin madde tanımada, yüksek sıklıktaki kelimelerin de çağrışımsal tanıma testinde avantajlı olduğu bulunmuştur. Özetle, kelimelerin kullanım sıklığı madde ve çağrışım belleğini farklı etkilemiştir ve bu da iki görevin birbirinden farklı mekanizmaları aktive edebileceğini göstermektedir.

Ayrıca, Hockley ve Cristi (1996) madde ve çağrışım odaklı kodlamanın madde ve çağrıșım bilgisini fark11 etkilediğini göstermiştir. Bütün katılımcılar kelime çiftlerini çalıştıktan sonra katılımcıların yarısına kelimelere ayrı ayrı odaklanmaları gerektiğini, çünkü kelime tanıma testi göreceklerini; diğer yarısına ise kelimeleri çift olarak çalışmalarını, çünkü çağrışımsal tanıma testi göreceklerini söylemişlerdir. Fakat, her iki gruba hem madde tanıma hem çağrışımsal tanıma testi uygulamışlardır. Kelime bazında çalışmalarını istedikleri katılımcılar, madde tanıma testinde çağrışımsal tanıma testine kıyasla daha başarılı olmuşlardır. Ancak, çiftleri birlikte çalışan katılımcılar madde tanıma ve çağrışımsal hatırlama testlerinde eşit derecede başarılı olmuşlardır. Yani madde odaklı çalışmak çağrışım bilgisine zarar verirken, çağrışım odaklı çalışmak madde bilgisine zarar vermemiştir. Bu çalışma da yine madde ve çağrışım bilgilerinin farklı süreçler ile işlendiği görüşünü desteklemektedir.

Bunlara ek olarak Buchler, Light ve Reder (2008) madde ve çağrışım bilgilerini farklı bir yöntemle kıyaslamışlardır. Bu araştırmada kelime çiftlerinden bazıları beş kere gösterilmiş, bazı kelimeler ise çeşitli kelimelerle eşlenerek beş kere gösterilmiştir. Yani iki grupta da kelimeler eşit derecede güçlendirilmiş, ancak ilk grupta kelimeler arasındaki ilişki de güçlendirilmiştir. Test sırasında ise bu çiftlerin çalışma kısmında gösterilip gösterilmediği sorulmuştur. Araştırmanın sonuçları beş kere gösterilen çiftlerin farklı kelimelerle gösterilen çiftlere göre daha iyi hatırlandığını göstermektedir Yazarların yaptığı çıkarıma göre bu fark çağrışım bilgisinin de güçlenmiş olmasından gelmektedir çünkü iki grupta da beş kere gösterilen kelimeler sorulmuş olup, yalnızca birlikte güçlendirilen çiftler daha iyi hatırlanmıştır. Bu nedenle çağrışım bilgisinin madde bilgisine ek olarak kaydedildiği sonucuna varıp madde ve çağrışım bilgilerinin çağrışımsal hatırlama görevine farklı katkı sunduklarını öne sürmüşlerdir.

Tüm bu araştırmaların yanında, madde ve çağrışım bilgilerinin nasıl kaydedilip hatırlandığ 1 yakın zamanda Cox ve Criss (2017) tarafindan incelenmiştir. Deney ve modelleme yöntemleriyle yapılan kapsamlı araştırmada madde ve çağrışım bilgilerinin farklı bellek depolarında veya tek bir bellek izinde farklı özelliklerle kaydedildiği sonucuna varmışlardır. Sonuç olarak madde ve çağrışım bilgileri farklı şekillerde kodlanır, farklı sürelerde geri çağrılır, maddelerin kullanım sıklığı özelliklerinden farklı etkilenir ve unutulmaya farklı şekillerde yatkınlardır. Bu da madde ve çağrışım bilgilerinin aynı olarak farz edilmeyip birbirinden bağımsız araştırılması gerektiğini göstermektedir.

\section{Çağrıșım Bilgisi Nasıl Kodlanır?}

Birçok nedenle madde bilgisinden farklı olan çağrışım bilgisinin öğrenilmesi belirli bir dikkat ve maddeler arasında ilişki kurma çabasını gerektirmektedir. Bu ilişkiyi kurmak için kullanılan bazı etkili yöntemler vardır (Murdock, 1997). Bunlardan ilki, kelimeleri ortak bir resimde akılda canlandırmaktır. Örneğin, "sınıf-yastık" kelime çiftini akılda tutmak için sınıfın içinde bir yastık düşünmek, yani bu iki kelimeyi birlikte hayal etmek, aralarında ilişki kurmayı kolaylaştıracaktır. Bir diğer etkili yöntemse iki kelimeyi aynı cümlede kullanmaktır. Yine "sınıf-yastık" kelime çiftini ele alacak olursak, "Öğretmen sinıfa yastık getirdi." cümlesini kurmak bu iki kelimenin birlikte hatırlanma ihtimalini arttıracaktır. Kullanılan bir diğer etkili yöntem ise aracı kelime kullanmaktır. Örneğin, "kılıf” kelimesini "sınıf-yastık" çifti için aracı olarak kullanmak (sınıf-kılıf-yastık) iki kelimeyi ilişkilendirmeyi kolaylaştıracaktır. Hangi yöntemin ne zaman daha etkili olduğu kelime çiftine ve kullanacak kişiye göre değişebilir. Kimi insanlar akılda canlandırmada daha başarılıyken kimileri cümle kurmakta daha başarılıdır. Kimi kelime çiftleri akılda canlandırılmaya daha yatkınken kimileri aracı kelime bulunmasına veya cümle içinde kullanılmaya daha yatkındır.

Tek seferlik verimli ilișkilendirmenin çağrışımları öğrenmek için yeterli olup olmadığı tartışma konusu- 
dur. Yani bir kere "sınıf" ve "yastık" kelimelerini etkili bir şekilde hayal etmenin o kelime çiftinin öğrenildiği anlamına gelip gelmediği konusunda çeşitli hipotezler bulunmaktadır. Öğrenme grafiğinin çalışma sayısı ile doğru oranda artması her tekrarın kelimeler arasındaki çağrışım bağını güçlendirdiğini düşündürmüştür (Kristofferson, 1961; Underwood, Rehula ve Keppel, 1962). Ancak Rock (1957) bu grafiği farklı şekilde yorumlamıştır ve "ya hep ya hiç öğrenme" hipotezini öne sürmüştür. Rock'a göre öğrenme tek denemede gerçekleşir ve öğrenme grafiğindeki artış, bazı çiftlerin ilerleyen çalışmalarda öğrenilmesinden kaynaklanmaktadır. Yani listedeki bazı çiftler ilk çalışmalarda, bazı çiftlerse ilerleyen çalı̧̧alarda öğrenilir ve bu durum öğrenme grafiğini arttırır. Bu zıt görüşlerden varılan sonuç ise şu olmuştur: çağrışımsal öğrenme, gösterilen kelimelerin ilişkilerinin güçlendirildiği mekanik bir süreç değil; onun yerine insanların stratejiler kullanarak yeni bilgiyi eski bilgilerle ilişkilendirmesine dayanan karmaşık bir süreçtir (Rock ve Ceraso, 1964).

Çăğıșım bilgilerinin öğrenilmesini destekleyen bir diğer etken de test ediliyor olmanın kendisidir. Testin bellek performansını artırdığı çeşitli araştırmalarla tekrar edilmiştir ve test etkisi olarak da adlandırılan bu etki, teste doğru cevap vermenin bellekteki bilgiyi güçlendirmesi olarak tanımlanmıștır (Ariel \& Karpicke, 2017; Bjork, 1975; Carrier ve Pashler, 1992; Glover, 1989; Karpicke, 2017; Roediger ve Butler, 2011; Roediger ve Karpicke, 2006). Ancak, şuna da dikkat çekmek gerekir ki teste doğru cevap vermek aynı zamanda cevabı görüp tekrar çalışmayı sağladığı için hem tekrar çalışma hem de test edilme etkileri birlikte belleği güçlendirmektedir. Bu da, tekrar çalışmanın mı yoksa test edilmenin mi daha etkili bir yöntem olduğu bilgisi net değildir. $\mathrm{Bu}$ farkı anlayabilmek adına bir koşulda katılımcıların çalı̧̧ma kısmından sonra tekrar çalıştığı (çalışma - çalışma) diğer koşulda ise çalıştıktan sonra test edildiği (çalışma - test) ve her iki grubun da bu setlerden sonra test edildiği deneyler düzenlenmiştir. Bu yöntem ile yapılan çalı̧̧malarda test edilmenin tekrar çalışmaya göre bellek performansını daha iyi etkilediği defalarca tekrarlanmıştır (Ariel \& Karpicke, 2017; Carrier ve Pashler, 1992; Karpicke ve Roediger, 2008). McDaniel, Kowitz ve Dunay (1989)'a göre test edilmek A-B ilişkisinin detaylandırılıp tekrar kodlanmasını sağladığı için öğrenmeyi kuvvetlendirmektedir.

Çağrışımların nasıl öğrenildiğini açıklamaya çalş̧an bunca araştırmadan sonra bir başka soru akla gelebilir: Kelimelerin gösterilme sıraları çağrışımın öğrenilmesini etkilemiyor mu? Bir sonraki bölümde çalışılan çiftler arasındaki ilişkinin tek yönlü yani bağımsız olduğu mu yoksa çift yönlü yani simetrik mi olduğu tartışılacaktır.

\section{Simetrik Çağrıșım ve Bağımsız Çağrışım Hipotezleri}

Çağrışım belleğinde maddelerin kaydedilip geri çağrılmasını açıklamaya çalışan iki temel hipotez vardır. $\mathrm{Bu}$ hipotezler de çağrışım belleği görevlerinde sıklıkla kullanılan kelime çiftlerini temel almaktadır. Bir ipuçlu hatıllama görevinde X-Y kelime çifti çalışma kısmında gösterildikten sonra test kısmına geçildiğinde $\mathrm{X}$ kelimesi ipucu olarak verilip Y kelimesinin hedef olarak hatırlanması isteniyorsa bu ileriye yönelik çağrışım gerektirmektedir (Epstein ve Dupree, 1977). Basit bir şekilde tanımlamak gerekirse ilk kelimenin ipucu olarak verilip ikinci kelimenin hedef kelime olarak bulunmasını istemek ileriye doğru çağrışım yaptırmak demek olur. Geriye doğru çağrışım görevinde ise, test kısmında Y kelimesi ipucu olarak verilir ve katılımcının X kelimesini hatırlaması geriye doğru çağrışımı gerektirir. $\mathrm{Bu}$ da kelime çiftinden ikinci kelimenin ipucu olarak verilip ilk kelimenin hedef olarak bulunmasının istenmesi geriye doğru çağrışım yapılmasına neden olur. İleriye ve geriye doğru çağrışım, çağrışımsal tanıma görevinde de test kısmında değişimlenebilir. A-B çiftleri çalışıldıktan sonra test kısmında katılımcılara çifti görüp görmediği eğer A-B olarak soruluyorsa ileriye doğru çağrışım, B-A olarak soruluyorsa geriye doğru çağrışım yapılmış olur.

$\mathrm{Bu}$ iki test yöntemi dışında, çağrışım yönü, serbest hatıllama (free recall) testinde de araştırılır. Katılımcılara bir liste kelime sunulur ve çalışmaları istenir. Ardından çeldirici görev verilir ve test aşamasına geçilir. Bu aşamada katılımcılardan çalıştıkları kelimeleri hatırladıkları sirada rapor etmeleri istenir. Bu test yönteminde ileriye ve geriye doğru çağrışım kiş̧ilerin kelimeleri yazma sırası üzerinden yapılan analiz ile ölçülür. Bir kelimeyi söyledikten sonra ondan sonrakini söylemeye yatkınlarsa ileriye yönelik çağrışım, öncekini söylemeye yatkınlarsa geriye yönelik çağrışım yaptıkları anlamına gelir.

Tüm bu bilgiler ışığında, çağrışımın simetrik olup olmadığı üzerine iki temel hipotez bulunmaktadır. Bağımsız çağrışım hipotezine göre (BÇH) A-B ile B-A çağrışımı birbirinden farklıdır, yani ileriye ve geriye doğru çağrışımlar birbirinden bağımsız olarak kurulur (Kahana, 1996; Wolford, 1971). Bu durumda bu hipotez, A-B çağrışımının B-A çağrışımından istatistiksel olarak farklı oluşturulduğunu savunur. Buna karşın, Simetrik Çağrışım Hipotezi (SÇH) ise ileriye ve geriye doğru çağrışımın birbirinden farksız olduğunu, çiftlerin bir bütün olarak öğrenildiğini ve çağrışımın simetrik olduğunu savunur (Asch ve Ebenholtz, 1962; Kahana, 2002; Murdock, 1966).

Literatürde iki hipotezi destekleyen çalışmalar da bulunmaktadır. BÇH'yi destekleyen ilk bulgular Ebbinghaus (1885/1913)'un çalışmalarından gelmektedir. Ebbinghaus anlamsız hecelerden oluşan bir liste (ör., hab-bec-cob-odi-elu) ile serbest hatırlama testi yapmıştır 
ve insanların ileriye doğru ve geriye doğru çağrışımlar yaptıklarını bulmuştur. Yaptığı analiz sonucunda bir hecenin kendinden sonraki hece ile peş peşe söylenme oranı kendisinden önceki hece ile peş peşe söylenme oranından anlamlı bir farkla daha fazla çıkmıştır. Örneğin, listedeki "bec" hecesinden sonra "cob" hecesinin gelme oran1, "hab" hecesinin gelme oranından daha fazla çıkmıştır. Bu sonuçlar serbest hatırlama testinde çağrışımların ileriye yönelik kurulma oranının daha fazla olduğunu, böylece ileriye ve geriye doğru çağrışımın birbirlerinden farklı olduklarını ortaya koymuştur. Daha sonra farklı amaçlarla yapilan serbest hatırlama deneylerinde de bu asimetri desteklenmiştir (Howard ve Kahana, 1999; Kahana, 1996; Kahana, Howard, Zaromb, ve Wingfield, 2002).

$\mathrm{Bu}$ çalışmalar dışında Kahana (1996) serbest hatırlama testinde verilen cevaplar üzerinden yaptığı analizle insanların bir kelimeyi hatırladıktan sonra peşinden geleni hatırlamaya öncesinden geleni hatırlamaktan iki kat daha yatkın olduklarını bulmuştur. Bitişiklik (contiguity) etkisi olarak da bilenen bu bulgu serbest hatırlama testindeki en güçlü etkilerinden birisidir (Kahana,1996). Diğer taraftan, Schwartz, Howard, Jing, ve Kahana (2005) tanıma belleğinde bitişiklik etkisine baktıklarında bitişiklik etkisinin ileriye ve geriye dönük olarak benzer seviyelerde olduğunu göstermişlerdir. Sundukları bulgulara göre peş peşe doğru cevaplanan iki kelime eğer çalışma kısmında peş peşe gösterilmişse ve katılımcılar ilk kelimeyi emin olarak tanımışlarsa, ikinci kelimenin yine emin olarak tanınma oranı daha yüksektir. Benzer şekilde, çalışma listesindeki iki ardışık kelimeden ikincisi emin olarak tanınmışsa, daha sonra test edilen birinci kelimenin de emin olarak doğru tanınması daha olasıdır. $\mathrm{Bu}$ çalışma kısaca bitişiklik etkisinin tanıma belleğinde de gözlendiğini belirttiği gibi, bu etkinin serbest hatırlamadan farklı olarak ileri ve geriye yönelik çağrışımların benzer olduğunu yani simetrik olarak ortaya çıktığını göstermiştir.

Sonrasinda, Kahana ve Caplan (2002) üçlü yoklayıcı hatırlama kullanarak ileriye doğru hatırlamanın avantajlı olduğu bulgusu ile BÇH'yi destekleyen sonuçlar bulmuşlardır. Thomas, Milner ve Haberlandt (2003) yaptıkları deneyde dörtlü ve altılı kelime listeleri kullandıklarında da katılımcıların ileriye doğru çağrışımı geriye doğru çağrışımdan daha çok kullandıklarını bulmuştur. Ancak Caplan, Glaholt ve McIntosh'un (2006) deneyinde kelime çiftleri ve üçlüleri ipuçlu hatırlama testi ile kıyasladıklarında üçlülerde bir asimetri gözlemlememişlerdir. Kahana ve Caplan'ın (2002) çalışmasından farklı olarak bu deneyin çalışma kısmında kelime çiftlerini bir kere göstermiş olmanın bu sonuca neden olmuş olabileceğini not etmişlerdir. Yani, çalışma kısmındaki farklı değişimlemeler simetri/asimetri sonuçlarında bir farka sebep olmaktadır.
Simetrik çağrışım hipotezinin test edildiği bir başka çalışmada ise yine çalışma aşamasında kelime çiftleri sunulmuştur. Test aşamasında ise çalışma kısmında gösterilen çiftlerin yarısı aynı sırayla (ileriye doğru çağrışım), diğer yarısı da ters sırayla (geriye doğru çağrışım) sunulup çağrışımsal tanıma görevi kullanılmıştır. Bu yöntem ile yapılan deneylerde ileriye doğru gösterilen çiftlerin geriye doğru gösterilen çiftlerden daha hızlı ve daha doğru tanındığı bulunmuştur (Wiegand, Bader, ve Mecklinger, 2010; Yang ve arkadaşları, 2013). Bu da daha önce de belirttiğimiz gibi farklı çalışma ve test değişimlemelerin bellekteki çağrışımları simetrik veya asimetrik olarak farklı etkileyebileceğini göstermektedir.

Üçlü yoklayıcı hatırlama, dörtlü/altılı listelerin kullanımı, serbest hatırlama, ve çağrışımsal tanıma görevlerinde bir asimetri ortaya çıktığı gözlemlenmişken ipuçlu hatırlama görevinde kelimeler arasında simetrik çağr1Ş1m olduğu bulunmuştur (Madan ve arkadaşları 2010; Mandler, Rabinowitz, ve Simon, 1961; Murdock, 1965, 1966). Bu çalışmalara göre Gestalt prensiplerine dayandırılarak ipuçlu hatırlamada eğer ileriye doğru ve geriye doğru performans istatistiksel olarak farklı çıkmazsa simetri bulunduğu ileri sürülebilir (Asch ve Ebenholtz 1962). Ancak Kahana (2002)'ya göre simetrik ve bütüncül bir çağrışımın olup olmadığına her çiftin hem ileriye doğru hem de geriye doğru test edilmesi ile bakılabilir. Yani Kahana’ya göre kelimeler arasında simetri olduğunu desteklemek için aynı çiftin ileriye ve geriye doğru testinin aynı çağrışımsal gücü göstermesi gerekmektedir. $\mathrm{Bu}$ durumda yalnızca ortalama performans değerlerine bakılması yeterli olmayacağı için, iki test arasındaki korelasyonu ölçmek de gerekmektedir. Örneğin, A-B ve C-D çiftlerinden oluşan bir listeden sonra katılımcılar her bir çift ile iki kere test edilir. Bunun sonucunda bir katılımcı A-? ve ?-D sorularını doğru yanıtlarken, ?-B ve $\mathrm{C}-$ ? sorularını yanlış yanıtlayabilir. Bu durumda performansın ortalama değerleri simetrik çıkacaktır çünkü ileriye doğru ve geriye doğru durumlarda birer doğru ve birer yanlış bulunmaktadır. Ancak, A-?'ni doğru bilirken ?-B'yi bilememek bir asimetri göstergesidir çünkü ileriye doğru sorulduğunda cevap alınmış fakat geriye doğru sorulduğunda cevap alınamamıştır. Yani korelasyona bakıldığında çiftlerin bütün olarak öğrenilmediği, bir asimetri olduğu görülmektedir. Bir başka katılımcının da A-? ve ?-B sorularını doğru yanıtlarken C-? ve ?-D sorularını yanlış yanıtladığı durumda performans ortalamasından yine simetrik bir sonuç çıkmaktadır ancak, bu sefer korelasyon da eşit çıkmıştır. A-? ile ?-B sorularına doğru yanıt vermek ve C-? ve ?-D sorularına yanlış yanıt vermek ileriye ve geriye doğru testlerde eşit performans çıktığının göstergesidir. Yani ancak böyle bir durum sağlandığ takdirde simetrik ve bütüncül bir öğrenme söz konusu olabilir. Bu da tek başına ortalama performans- 
lara bakmak sonuçları doğru yorumlamak için yeterli olamayacağı anlamına gelir. Bunun araştırılabilmesi için de iki testli yöntem kullanılmalıdır. Kısaca, çiftlerin iki farkl1 testte ileri-ileri, ileri-geri, geri-ileri ve geri-geri şeklinde sorulduğu bir ipuçlu hatırlama testi oluşturarak Kahana, her olasılığın değerlendirildiği bir test yöntemi ortaya koymuştur.

Kahana'nın geliştirdiği bu test yöntemi kullanılarak yapılan ipuçlu hatırlama testlerinde de simetri bulunmuştur (Caplan, ve arkadaşları, 2006; Kahana, 2002; Madan ve arkadaşları, 2010; Rehani ve Caplan, 2011; Sommer, Schoell, ve Büchel, 2008; Sommer, Rose ve Büchel, 2007). Kahana (2002) bu yöntemi ilk defa kullandığı makalesinde test 1 ve test 2 arasında ileriye ve geriye doğru çağrışımlar arasında fark bulmamıştır. Caplan ve arkadaşları (2006) kelime çiftlerini ve kelime üçlülerini kıyasladıkları çalışmalarında, kelime çiftlerinin test 1 ve test 2 korelasyonunda ileriye doğru ve geriye doğru çağrışımında performansı farklı bulamamışlardır. Sommer ve arkadaşları (2007) da obje ve konum ile oluşturdukları kelime çiftleri için yine test 1 ve test 2 arasındaki korelasyon aracılığ ile herhangi bir fark bulamamışlardır. Madan ve arkadaşları (2010) da kelimelerin imgelem ve sıklık özelliklerinin ipuçlu hatırlamaya etkisini araştırdıkları makalelerinde ikili test yöntemini kullandıklarında yine simetrik çağrışım hipotezini destekleyen sonuçlar bulmuşlardır. Son olarak, Yang ve arkadaşları (2013) birbiriyle alakalı ve alakasız çiftleri ve üçlüleri kıyasladıkları çalışmalarında ikili test yöntemini kullanmış ve fark bulamamışlardır. Tüm bu sonuçlar bize gösteriyor ki kelime çiftleri ipuçlu hatırlama yöntemi ile test edildiğinde sonuçlar SÇH'yi desteklemektedir.

Ancak, Popov ve arkadaşları (2019) anlamsal (semantic) olarak birbirine yakın kelime çiftlerini ipuçlu hatırlamada test ettikleri bir araştırma yaptıklarında bu kelime çiftleri için ileriye doğru çağrışımın avantajlı olduğunu göstermişlerdir. Bu da demek oluyor ki, diğer deneylerin aksine, anlamsal olarak birbirine yakın kelimeleri çift olarak sunmak simetrik çağrışımı ortadan kaldırmıştır. Benzer bir araştırma ile birleşik kelime oluşturan çiftlerde ipuçlu hatırlamayı araştıran Caplan, Boulton ve Gagne (2014) yine asimetri gözlemlemiştir. Ayrica Vaughn ve Rawson'un (2014) kriter seviyesinin çağrışım belleğine etkisine baktıkları araştırmalarında ipuçlu hatırlama görevinde asimetri bulmuşlardır. Bu nedenle, her ipuçlu hatırlama testi için bir simetri olduğunu söylemek yanıltıcı olabilir. Bu durumu etkileyen çeşitli faktörler anlamsal belleğin de dahil edildiği daha detaylı araştırmalar sonucunda netleşecektir.

Özetleyecek olursak, literatürde çağrışımların bütüncül olup olmadığına dair iki temel hipotez bulunmaktadır: simetrik çağrışım hipotezi ve bağımsız çağrışım hipotezi. Çağrışımın ileriye ve geriye doğru farklı şe- killerde oluşturulduğunu savunan $\mathrm{BÇH}$ yoklayıı hatırlama, dörtlü/altılı listelerin kullanımı, serbest hatırlama ve çağrışımsal tanıma testleri ile desteklenmişken; çağrışımların bir bütün olarak, yönü olmadan oluşturulduğunu savunan SÇH ise ipuçlu hatırlama testi ile yapılan araştırmalarla desteklenmiştir. Bu bilgiler 1şı̆̆ında şöyle bir çıkarıma ulaşabiliriz: ipucu kelimeleri katılımcılara (ipuçlu hatırlama ya da tanıma görevinde olduğu gibi) deneyci tarafından verildiğinde asimetri ortadan kaybolurken, sıralamanın katılımcı tarafından belirlendiği görevlerde (serbest hatırlama, sıralı hatırlama, yoklayıı1 hatırlama gibi) maddeler arasındaki ilişki zamansal olarak geri çağrılıyor ya da zamandan faydalanılıyor ve bu da bir asimetrinin oluşmasına sebep olabilir. Ancak bazı ipuçlu hatırlama görevlerinde asimetri bulunuyor olması bu sorunun hala yanıtlanamadığını göstermektedir. Bu konuda literatürde çağrışımsal simetri ve asimetrinin hangi şartlarda ne şekilde ortaya çıktığının araştırılması önem taşımaktadır.

\section{Sonuc}

Günlük hayatta farkında bile olmadan olayları ve nesneleri birlikte ögrenip birbiri sayesinde hatırlarız. Aslında sürekli olarak çağrışım belleğinden faydalanmaktayız. Bu nedenle çağrışımların olaysal bellek üzerindeki faydalarının araştırılması belleğin çalışma süreçlerini daha detaylı anlaşılmasına büyük katkı sağlayacaktır. Çağrışım belleğini araştırmak için kullanılan iki temel görev, ipuçlu hatırlama ve çağrışımsal tanıma, çalışma aşamasında öğrenilen kelime çiftlerinin birbirleri ile nasıl ilişkilendirildiğini anlamak için geliştirilmiştir. $\mathrm{Bu}$ görevlerden elde edilen sonuçlara göre kelimelerin içerik (madde) ve çağrışım bilgilerinin nasıl bir süreçten geçtiği bu makale kapsamında incelenmiştir.

Öncelikle, madde ile çağrışım bilgilerinin ne ölçüde birbirlerinden farklı olduğu tartışılmıştır. Örneğin çağrışım bilgisi bellekten geri çağırılırken madde bilgisine kıyasla daha yavaş birikir (Gronlund ve Ratcliff, 1989). Benzer şekilde, madde ve çağrışım bilgilerinin kodlanması da farklı süreçler gerekiyor olabilir. Örneğin, McGee (1980)'nin araştırmasına göre tek tek gösterilen maddeler listedeki diğer maddelerden ayrı hayal edildiğinde, çift olarak gösterilen kelimelerse birlikte hayal edildiklerinde daha iyi hatırlanmışlardır. Yani madde ve çağrışım bilgileri farklı şekillerde kodlanırlar. Hockley'nin (1992) çalışmasına göre ise çağrışımsal tanıma test performansında zamana bağlı bir düşüş gözlemlenmezken madde tanıma testi performansında zamana bağ11 düşüş bulunmuştur. Bu da madde ve çağrışım bilgilerinin farklı sürelerde unutulduğunu göstermektedir. Ayrıca Clark ve Burchett (1994)'in çalışması madde ve çağr1şım bilgisinin kelimelerin kullanım sıklığı özelliğinden 
farklı etkilendiğini ortaya çıkarmıştır. Son olarak, Hockley ve Cristi (1996) kelime (madde) odaklı çalışmanın çağrışım bilgisine zarar verdiği halde, çağrışım odaklı çalışmanın kelime bilgisine zarar vermediğini göstermiştir. Tüm bu bulgular çağrışım ve madde bilgilerinin birbirlerinden farklı türler olduğunu ve farklı şekillerde ele alınıp çalışılması gerektiğini göstermektedir. Öyle ki, Buchler ve arkadaşları (2008) madde ve çağrışım bilgilerinin çağrışım belleğine farklı katkı sundukları sonucuna varmışlardır. Ancak çağrışım belleğinde madde bilgisinin rolü, çağrışım ve madde bilgisinin etkileşimi gibi konular hakkında deneysel verinin artması çağrışım belleği mekanizmasını tanımlayan modellerin geliştirilmesi açısından gereklidir.

Madde bilgisinden farklı olan çağrışımların kodlanmasını etkileyen çeşitli faktörler vardır. Maddelerin ne şekilde ilişkilendirildiği öğrenilme oranlarını etkilemektedir ve üç temel etkili yöntem bulunmaktadır: hayal etme, cümle kurma, aracı bulma. Ayrıca, test edilmenin de çağrışımların öğrenilmesine faydası olduğu bulunmuştur.

İki kelime arasında oluşan çağrışımın yapısı üzerine sunulan iki hipotezden biri olan simetrik çağrışım hipotezi çiftlerin bir bütün olarak öğrenildiğini, bu nedenle ileriye ve geriye doğru çağrışım performanslarının birbirinden farklı çıkmayacağını savunurken, bir diğer hipotez, bağımsız çağrışım hipotezi, ileriye ve geriye doğru çağrışımın birbirinden bağımsız olduğunu ve çiftlerin bütün olarak öğrenilmediğini savunur. İki hipotezi de destekleyen çeşitli çalışmalar bulunmaktadır. Ancak, en önemlisi Kahana'nın geliştirmiş olduğu iki testli ipuçlu hatırlama yöntemine göre çiftlerin bütünsel olarak öğrenildiği ve çiftleri oluşturan kelimelerin çağrışımları arasında bir simetri olduğu bulunmuştur. $\mathrm{Bu}$ da ipuçlu hatırlama görevlerinde simetrik çağrışım hipotezini desteklemektedir. Diğer taraftan, Popov ve arkadaşları (2019), Caplan ve arkadaşları (2014) ve Vaughn ve Rawson (2014) ipuçlu hatırlama görevinde ileriye doğru hatırlamanın avantajlı olduğunu bulmuşlardır. Yani kullanılan test yöntemi ve seçilen kelime grupları çağrışımın simetrik veya asimetrik olma durumunu farklı şekillerde etkilemektedir. Ancak literatürde simetri ve asimetrinin nedenleri hala tam anlamıyla ortaya konmamıştır. $\mathrm{Bu}$ nedenle asimetrinin ve simetrinin gözlemlendiği durumların hangi açılardan farklılaştığını ve farklı sonuçlara yol açtığını araştırmak çağrışımsal belleğin altında yatan mekanizmaları anlamak açısından önem sarf etmektedir.

Tüm bu bilgiler 1şı̆̆ında anlaşılan o ki çağrışım belleği günümüze kadar kapsamlı bir şekilde araştırılmıştır ancak buna rağmen hâlâ daha birçok soru barınd1ran geniş bir alandır. Çağrışımsal ilişkinin nasıl kurulduğu, bu ilişkinin hangi durumlarda yönlü olduğu, simetrinin genellenebilirliği, madde bilgisinden farklı olurken ondan ne derece beslendiği hala araştırılması gereken önemli sorulardır. Bu soruların cevaplanması çağrışım belleğinin mekanizmasını açıklamaya çalışan modellerin de gelişmesi için önem sarf etmektedir Buna ek olarak çağrışım belleğinin araştırılması ve olaysal bellek ile anlamsal bellek arasındaki ilişkilerin daha açık bir biçimde belirlenebilmesi, en genelde belleğin temel çalışma prensiplerini anlamak adına büyük önem taşımaktadır. 


\section{Kaynaklar}

Ariel, R., \& Karpicke, J. D. (2017). Improving self-regulated learning with a retrieval practice intervention. Journal of Experimental Psychology: Applied, 24, 43-56. doi: 10.1037/xap0000133.

Asch, S. E., \& Ebenholtz, S. M. (1962). The principle of associative symmetry. Proceedings of the American Philosophical Society, 106(2), 135-163.

Aue, W. R., Fontaine, J. M., \& Criss, A. H. (2018). Examining the role of context variability in memory for items and associations. Memory \& cognition, 46(6), 940-954.

Bjork, R. A. (1975). Retrieval as a memory modifier: an interpretation of negative recency and related phenomena. In Robert L. Solso (ed.), Information Processing and Cognition: The Loyola Symposium (pp. 123-144). NJ: Erlbaum.

Buckmaster, C. A., Eichenbaum, H., Amaral, D. G., Suzuki, W. A., \& Rapp, P. R. (2004).Entorhinal cortex lesions disrupt the relational organization of memory inmonkeys. Journal of Neuroscience, 24(44), 9811-9825.

Buchler, N. G., Light, L. L., \& Reder, L. M. (2008). Memory for items and associations: Distinct representations and processes in associative recognition. Journal of Memory and Language, 59(2), 183-199.

Caplan, J. B., Boulton, K. L., \& Gagné, C. L. (2014). Associative asymmetry of compound words. Journal of Experimental Psychology: Learning, Memory, and Cognition, 40(4), 1163.

Caplan, J. B., Glaholt, M. G., \& McIntosh, A. R. (2006). Linking associative and serial list memory: Pairs versus triples. Journal of Experimental Psychology: Learning, Memory, and Cognition, 32(6), 1244-1265.

Carrier, M., \& Pashler, H. (1992). The influence of retrieval on retention. Memory and Cognition, 20(6), 633-642.

Ceraso, J., \& Henderson, A. (1965). Unavailability and associative loss in in RI and PI. Journal of Experimental Psychology, 70, 300-303.

Clark, S. E. (1992). Word frequency effects in associative and item recognition. Memory and Cognition, 20(3), 231-243.

Clark, S. E., \& Burchett, R. E. (1994). Word frequency and list composition effects in associative recognition and recall. Memory and Cognition, 22(1), 55-62.

Clark, S. E., \& Shiffrin, R. M. (1992). Cuing effects and associative information in recognition memory. Memory and Cognition, 20(5), 580-598.
Cox, G. E., \& Criss, A. H. (2017). Parallel interactive retrieval of item and associative information from event memory. Cognitive Psychology, 97, 31-61.

Cox, G. E., Hemmer, P., Aue, W. R., \& Criss, A. H. (2018). Information and processes underlying semantic and episodic memory across tasks, items, and individuals. Journal of Experimental Psychology: General, 147(4), 545.

Criss, A. H., Aue, W. R., \& Smith, L. (2011). The effects of word frequency and context variability in cued recall. Journal of Memory and Language, 64(2), 119-132.

Davis, O. C., Geller, A. S., Rizzuto, D. S., \& Kahana, M. J. (2008). Temporal associative processes revealed by intrusions in paired-associate recall. Psychonomic Bulletin \& Review, 15(1), 64-69.

Dennis, S., \& Kruschke, J. K. (1998). Shifting attention in cued recall. Australian Journal of Psychology, 50(3), 131-138.

Ebbinghaus, H. 1885/1913 Memory: A Contribution To Experimental Psychology. (H. A. Ruge ve C. A. Bussenius, Trans.). New York, NY: Teachers College, Columbia University.

Ensor, T. M., Guitard, D., Bireta, T. J., Hockley, W. E., \& Surprenant, A. M. (2019). The list-length effect occurs in cued recall with the retroactive design but not the proactive design. Canadian Journal of Experimental Psychology/Revue canadienne de psychologie expérimentale.

Epstein, M. L., \& Dupree, D. A. (1977). Category headings as recall cues: A test of the principle of encoding specificity. The Journal of general psychology, 97(1), 101-108.

Glover, J. A. (1989). The" testing" phenomenon: Not gone but nearly forgotten. Journal of Educational Psychology, 81(3), 392.

Gronlund, S. D., \& Ratcliff, R. (1989). Time course of item and associative information: Implications for global memory models. Journal of Experimental Psychology: Learning, Memory, and Cognition, 15(5), 846.

Haskins, A. L., Yonelinas, A. P., Quamme, J. R., \& Ranganath, C. (2008). Perirhinal cortex supports encoding and familiarity-based recognition of novel associations. Neuron, 59(4), 554-560.

Hintzman, D. L. (2016). Is memory organized by temporal contiguity?. Memory \& Cognition, 44(3), 365-375.

Hockley, W. E. (1991). Recognition memory for item and associative information: a comparison of forgetting rates. In William E Hockley \& Stephan Lewandowsky (eds.), Relating theory and data: Essays on human memory in honor of Bennet B. Murdock. (pp. 227-248). Hillsdale, NJ: Erlbaum. 
Hockley, W. E. (1992). Item versus associative information: Further comparisons of forgetting rates. Journal of Experimental Psychology: Learning, Memory, and Cognition, 18(6), 1321-1330.

Hockley, W. E. (1994). Reflections of the mirror effect for item and associative recognition. Memory \& Cognition, 22(6), 713-722.

Hockley, W. E., \& Cristi, C. (1996). Tests of encoding tradeoffs between item and associative information. Memory \& Cognition, 24(2), 202-216.

Howard, M. W., \& Kahana, M. J. (1999). Contextual variability and serial position effects in free recall. Journal of Experimental Psychology: Learning, Memory, and Cognition, 25(4), 923.

Humphreys, M. S. (1976). Relational information and the context effect in recognition memory. Memory and Cognition, 4(2), 221-232.

Humphreys, M. S. (1978). Item and relational information: A case for context independent retrieval. Journal of Verbal Learning and Verbal Behavior, 17(2), 175-187.

Jackson, A., \& Greene, R. L. (2017). Question order bias in retrospective evaluations of item and associative recognition. Memory, 25(4), 481-486.

Kahana, M. J. (1996). Associative retrieval processes in free recall. Memory and cognition, 24(1), 103-109.

Kahana, M. J. (2002). Associative symmetry and memory theory. Memory and Cognition, 30(6), 823840.

Kahana, M. J. (2012). Foundations of human memory. New York, NY, US: Oxford University Press.

Kahana, M. J., \& Caplan, J. B. (2002). Associative asymmetry in probed recall of serial lists. Memory and Cognition, 30(6), 841-849.

Kahana, M. J., Howard, M. W., \& Polyn, S. M. (2008). Associative retrieval processes in episodic memory. Psychology, 3.

Kahana, M. J., Howard, M. W., Zaromb, F., \& Wingfield, A. (2002). Age dissociates recency and lag recency effects in free recall. Journal of Experimental Psychology: Learning, Memory, and Cognition, 28(3), 530-540.

Karpicke, J. D. (2017). Retrieval-based learning: A decade of progress. In J. Wixted (Ed.), Cognitive psychology of memory, Vol. 2 of Learning and memory: A comprehensive reference (J. H. Byrne, Series Ed.). doi: 10.1016/B978-0-12-8093245.21055-9

Karpicke, J. D., \& Roediger, H. L. (2008). The critical importance of retrieval for learning. Science, 319(5865), 966-968.

Kilic, A., Criss, A. H., \& Howard, M. W. (2013). A causal contiguity effect that persists across time scales.
Journal of Experimental Psychology: Learning, Memory, and Cognition, 39(1), 297-303.

Kirwan, C. B., \& Stark, C. E. (2004). Medial temporal lobe activation during encoding and retrieval of novel face-name pairs. Hippocampus, 14(7), 919930.

Kristofferson, A. B. (1961). Repetition and paired associates learning. Science, 134(3495), 2036-2037.

Madan, C. R., Glaholt, M. G., \& Caplan, J. B. (2010). The influence of item properties on association-memory. Journal of Memory and Language, 63(1), 46-63.

Mandler, G., Rabinowitz, J. C., \& Simon, R. A. (1981). Coordinate organization: The holistic representation of word pairs. The American Journal of Psychology, 94(2), 209-222.

Mayes, A. R., Holdstock, J. S., Isaac, C. L., Montaldi, D., Grigor, J., Gummer, A., ... \& Gong, Q. (2004). Associative recognition in a patient with selective hippocampal lesions and relatively normal item recognition. Hippocampus, 14(6), 763-784.

McDaniel, M. A., Kowitz, M. D., \& Dunay, P. K. (1989). Altering memory through recall: The effects of cue-guided retrieval processing. Memory and Cognition, 17(4), 423-434.

McGee, R. (1980). Imagery and recognition memory: The effects of relational organization. Memory and Cognition, 8(5), 394-399.

Mohanty, P. P., \& Naveh-Benjamin, M. (2018). Mitigating the adverse effects of response deadline on recognition memory: Differential effects of semantic memory support on item and associative memory. Journal of Memory and Language, 102, 182-194.

Murdock Jr, B. B. (1965). Associative symmetry and dichotic presentation. Journal of Verbal Learning and Verbal Behavior, 4(3), 222-226.

Murdock Jr, B. B. (1966). Forward and backward associations in paired associates. Journal of Experimental Psychology, 71(5), 732-737.

Murdock, B. B. (1997). Context and mediators in a theory of distributed associative memory (TODAM2). Psychological Review, 104(4), 839.

Nobel, P. A., \& Shiffrin, R. M. (2001). Retrieval processes in recognition and cued recall. Journal of Experimental Psychology: Learning, Memory, and Cognition, 27(2), 384-413.

Osth, A. F., \& Fox, J. (2019). Are associations formed across pairs? A test of learning by temporal contiguity in associative recognition. Psychonomic Bulletin \& Review, 26(5), 1650-1656.

Paivio, A. (1969). Mental imagery in associative learning and memory. Psychological Review, 76(3), 241. 
Popov, V., Zhang, Q., Koch, G. E., Calloway, R. C., \& Coutanche, M. N. (2019). Semantic knowledge influences whether novel episodic associations are represented symmetrically or asymmetrically. $\mathrm{Me}$ mory \& Cognition, 47(8), 1567-1581.

Rehani, M., \& Caplan, J. B. (2011). Interference and the representation of order within associations. Quarterly Journal of Experimental Psychology, 64(7), 1409-1429.

Rock, I. (1957). The role of repetition in associative learning. The American Journal of Psychology, 70(2), 186-193.

Rock, I., \& Ceraso, J. (1964). Toward a cognitive theory of associative learning. In Constance Scheerer (ed.) Cognition: Theory, research and promise (pp. 110-146). New York: Harper and Row.

Roediger III, H. L., \& Butler, A. C. (2011). The critical role of retrieval practice in long-term retention. Trends in Cognitive Sciences, 15(1), 20-27.

Roediger III, H. L., \& Karpicke, J. D. (2006). The power of testing memory: Basic research and implications for educational practice. Perspectives on Psychological Science, 1(3), 181-210.

Schwartz, G., Howard, M. W., Jing, B., \& Kahana, M. J. (2005). Shadows of the past: Temporal retrieval effects in recognition memory. Psychological Science, 16(11), 898-904.

Sommer, T., Rose, M., \& Büchel, C. (2007). Associative symmetry versus independent associations in the memory for object-location associations. Journal of Experimental Psychology: Learning, Memory, and Cognition, 33(1), 90-106.

Sommer, T., Schoell, E., \& Büchel, C. (2008). Associative symmetry of the memory for object-location associations as revealed by the testing effect. Acta Psychologica, 128, 238-248.

Thomas, J. G., Milner, H. R., \& Haberlandt, K. F. (2003). Forward and backward recall: Different response time patterns, same retrieval order. Psychological Science, 14(2), 169-174.

Tulving, E. (1972). Episodic and semantic memory. In Endel Tulving ve Wayne Donalds (eds.), Organization of Memory (pp. 381-402). New York: Academy.

Tulving, E. (1985). How many memory systems are there?. American Psychologist, 40(4), 385-398.

Tulving, E. (1992). Episodic memory. In L. Squire (Ed.), Encyclopedia of Learning and Memory (pp. 161163). New York: Macmillan.

Tulving, E. (2002). Episodic memory: from mind to brain. Annual Review of Psychology, 53(1), 1-25.

Underwood, B. J. (1969). Attributes of memory. Psychological Review, 76(6), 559-573.
Underwood, B. J., Rehula, R., \& Keppel, G. (1962). Item-selection paired associate learning. The American Journal of Psychology, 75(3), 353-371.

Vaughn, K. E., \& Rawson, K. A. (2014). Effects of criterion level on associative memory: Evidence for associative asymmetry. Journal of Memory and Language, 75, 14-26.

Wiegand, I., Bader, R., \& Mecklinger, A. (2010). Multiple ways to the prior occurrence of an event: An electrophysiological dissociation of experimental and conceptually driven familiarity in recognition memory. Brain Research, 1360, 106-118.

Wilson, J. H., Kellen, D., \& Criss, A. H. (2020). Mechanisms of output interference in cued recall. $\mathrm{Me}$ mory \& Cognition, 1-18 doi.org/10.3758/s13421019-00961-1

Wolford, G. (1971). Function of distinct associations for paired-associate performance. Psychological Review, 78(4), 303-313.

Yang, J., Zhao, P., Zhu, Z., Mecklinger, A., Fang, Z., \& Li, H. (2013). Memory asymmetry of forward and backward associations in recognition tasks. Journal of Experimental Psychology: Learning, Memory, and Cognition, 39(1), 253.

Yonelinas, A. P., Hopfinger, J. B., Buonocore, M. H., Kroll, N. E. A., \& Baynes, K. (2001). Hippocampal, parahippocampal and occipital-temporal contributions to associative and item recognition memory: an fMRI study. Neuroreport, 12(2), 359-363. 


\section{Summary A Review on Association Memory}

\author{
Hatice Dedetaş \\ Middle East Technical University
}

\author{
Aslı Kılıç \\ Middle East Technical University
}

\begin{abstract}
Association Memory
Tulving $(1985,2002)$ defined episodic memory as the ability to remember personal events consciously, which includes temporal and spatial information. In episodic memory experiments, stimuli such as words, images, faces, sounds or fractals are studied for a subsequent test. In addition to item information, the associations formed among items are also important in understanding the mechanisms that underlie episodic memory. For example, the associations between items can be based on temporal proximity (Kahana, 2002), holistic (Madan, Glaholth, \& Caplan, 2010) or independently formed (Hockley \& Cristi, 1996). In short, understanding the mechanisms underlying the association memory is important for theoretical underpinnings.
\end{abstract}

\section{Association Memory Tasks}

Two main tasks are used to measure association memory: cued recall and associative recognition. There are two types of cued recall: study-test method and anticipation method. In the study-test method, word pairs $\left(X_{1}-Y_{1}, X_{2}-Y_{2}, X_{3}-Y_{3}, \ldots X_{n}-Y_{n}\right)$ are studied in a list and then one word is given as cue and its pair is asked $\left(X_{1}\right.$ ?, ? $2-\mathrm{X}_{2}, \mathrm{X}_{3}-$ ?, ... $\mathrm{Y}_{\mathrm{n}}-$ ?, Ensor, Guitard, Bireta, Hockley, \& Surprenant, 2019; Wilson, Kellen \& Criss, 2019). In the forward recall condition, Xs are presented as cues the paired Ys are required while in the backward recall condition, Ys are presented as cues and the paired Xs are required to be generated. The aim of this task is to measure whether the associations formed symmetrically by comparing the correct recall performance across two conditions. On the other hand, in the anticipation method, participants are presented with a word and they are given time to anticipate the other associated word. The associated word is presented if participants fail to anticipate (Kahana, 2012). This method further allows to measure the associations that were formed semantically.
Associative recognition is another task that measures how well sole associative information is encoded and retrieved. Again, word pairs are $\left(X_{1}-Y_{1}, X_{2}-Y_{2}\right.$, $\left.\mathrm{X}_{3}-\mathrm{Y}_{3}, \ldots \mathrm{X}_{\mathrm{n}}-\mathrm{Y}_{\mathrm{n}}\right)$ are studied and subsequently tested by recognizing whether the pairs are shown either in intact $\left(X_{1}-Y_{1}\right)$ or rearranged $\left(X_{2}-Y_{3}\right)$ pairs. Accordingly, this task allows researchers to measure the associative information of pairs by comparing accuracy of intact and rearranged pairs. Moreover, associative recognition task is also used to discriminate the effect of item and associative information on memory (e.g., Cox \& Criss, 2017; Gronlund \& Ratcliff, 1989; Jackson \& Greene, 2017; Hockley, 1992; Hockley \& Cristi, 1996; Nobel \& Shiffrin, 2001; Osth \& Fox, 2019).

In addition to presenting pairs of items, participants can study triplets (ABC) as Kahana and Caplan (2002) employed in a probed recall task. Later during test, one item cue (A?) or two item cues (AB?) are presented to elicit recall. These tasks are important for investigating whether pairs or triplets are forming symmetric and/or holistic associations or asymmetric and/or independent associations, which will be discussed further.

\section{The Difference Between Item and Associative Information}

According to Murdock (1972) and Humphreys (1976, 1978), item information represents the existence of the stimuli and its content while association information represents the relationship among items and events. The difference between item and associative information has been investigated through item and associative recognition tasks.

Gronlund and Ratcliff (1989) investigated accumulation of information by employing the response deadline procedure. Their results suggested that the time required for giving the correct answer was slower for associative recognition test than item recognition test. Further, they showed that more intact pairs were recalled correctly than single items, suggesting that the intact pairs includ-

Address for Correspondence: Res. Asst. Hatice Dedetaş, Middle East Technical University, Faculty of Arts and Sciences, Department of Psychology Dumlupınar Boulevard No:1, 06800 Çankaya / Ankara

E-mail: hdedetas@metu.edu.tr 
ed more distinctive and thus, stronger traces than single items do. By using a similar procedure, Mohanty and Naveh-Benjamin (2018) concluded that response deadline affects association memory more than item memory. Additionally, McGee (1980) also provided evidence for the difference between item and associative information. According to those results, if words are studied individually, the performance is better in item recognition test than associative recognition test. On the other hand, if the words are studied as pairs, the performance is better in associative recognition test than item recognition test. All those results suggest that the procedure of encoding items and pairs are different from one another.

When retrieval is considered, the rate of forgetting is also different for item information when compared with that for associative information. As Hockley (1992) suggested, the performance on item recognition test drops over time while the performance of associative recognition test is not affected.

Word frequency also affects item and associative information differently (Aue, Fontaine \& Criss, 2018; Clark, 1992; Clark \& Burchett, 1994; Clark \& Shiffrin, 1992; Hockley, 1994). Clark and Burchett (1994) found that high frequent words increased cued recall and associative recognition performance while low frequent words increased item recognition test performance.

Finally, Hockley and Cristi (1996) showed that item and association focused encoding affects item and associative information differently. If participants studied words of pairs individually, their item recognition test performance was greater than their associative recognition performance. However, if participants studied words of pairs together, their item and associative recognition test performance did not differ. This means that item-focused study impaired associative information while association-focused study did not affect item information.

Overall, item and associative information is encoded differently, forgotten in different time durations, they are affected by word frequency level differently and their forgetting tendency is different from one another.

\section{Associative Information: How is It Encoded?}

There are three effective ways of encoding associative information (Kahana, 2012). The first one is forming one mental image with two items (Pavio, 1969). The second one is forming a sentence by using two items. The third effective way is using a mediator. The effectiveness level of each method depends on the items and people using them (Kahana, 2012).

Another factor supporting the learning of associative information is the testing itself. Testing on the pairs increases performance more than studying pairs (Ariel \&
Karpicke, 2017; Bjork, 1975; Carrier ve Pashler, 1992; Glover, 1989; Karpicke, 2017; Roediger ve Butler, 2011; Roediger \& Karpicke, 2006). According to McDaniel, Kowitz and Dunay (1989), testing strengthens learning by causing elaboration and re-encoding of A-B relation.

\section{Symmetric Association and Independent Association Hypotheses}

In a cued recall task, for an $\mathrm{X}-\mathrm{Y}$ pair, presenting $\mathrm{X}$ as cue and asking for $\mathrm{Y}$ as target means forward recall while presenting $\mathrm{Y}$ as cue and asking for $\mathrm{X}$ as target is referred to as backward recall. On the other hand, in an associative recognition task, if the pair is presented as X-Y order in the test, it is called as forward association while $\mathrm{Y}-\mathrm{X}$ order is called as backward association. Moreover, in the free recall task, people's tendency to recall items in studied order is investigated. For example, when an item is recalled in a free recall task, if the subsequently recalled item is the following item in the study list, a forward recall was performed. If the preceding item in the study list is recalled, then a backward recall was performed. Contiguity effect shows a forward asymmetry suggesting that a forward recall is more probable than a backward recall.

Investigating the details of associative memory suggested two main hypotheses about symmetricity of associations. According to Independent Association Hypothesis (IHA), forward and backward recall is different from one another (Wolford, 1971; Kahana, 1996); performance on A-B association should be different from B-A association. In contrast to this hypothesis, Symmetric Association Hypothesis (SAH) argues that forward and backward associations are not different from one another and the associations are symmetric (Asch \& Ebenholtz, 1962; Murdock, 1966; Kahana, 2002).

As literature suggests, whether associations are formed as holistic or independent of the nature of the task. If the task is a probed recall, a free recall, an associative recognition task and short lists with a length of 4-6 items, the results support IAH (Ebbinghaus, 1885/1913; Kahana, Howard, Zaromb, \& Wingfield, 2002; Kahana, ve Caplan, 2002; Thomas, Milner, \& Haberlandt, 2003). On the other hand, if the task is a cued recall task, performance on the forward and the backward recall was comparable and thus SAH is supported (Kahana, 2002; Murdock, 1965, 1966; Mandler, Rabinowitz, \& Simon, 1961; Madan, Glaholt, \& Caplan 2010; Sommer, Rose, \&Büchel, 2007) with some exceptions (Caplan, Boulton \& Gagne 2014; Popov, Zhang, Koch, Calloway, \& Coutanche, 2019; Vaughn \& Rawson, 2014). 